\title{
肝動脈塞栓術施行或は非施行ヒト肝癌組織 の初代培養と株化
}

\author{
岡山大学医学部癌源研究施設病理部門（主任：佐藤二郎教授） \\ 日下 泰德, 常盤 孝義, 佐藤 二郎 \\ 岡山大学医学部第一外科学教室 (主任：折田薰三教授) \\ 津下 宏, 浜崎 啓介, 三村 久, 折田 薫三 \\ (昭和63年10月 25 日受稿)
}

Key words：TAE，上卜肝癌，初代培盖，株化

\section{緒 言}

原発性肝癌に由来する細胞株は, 肝細胞癌発 生に対する肝炎ウイルスの関与や, 腫禎マーカ 一の発現を初め, 肝細胞癌あるいは胆管細胞癌 の発生, 病因、䛦断、治療等の諸研究に欠かす ことのでさない材料である，現在までに肝細胞 癌に由来する細胞株を中心に数十例報告されて いるい-17が, 研究の一層の進展には未だ不十分 である、一般に肝癌の培㽰内株化は現在かなり 困難であると考えられている，肝癌の組織とし ての特異性もあるが，最大の理由として，現在 は種々の治療を経た手術材料が中心となるため, 細胞生存率の低下が避けられない18)ことによると 考之られる.今回, 我々は, 20例の肝動脈塞栓 術 (transcatheter arterial embolization 以下 TAE と略す）施行あるいは非施行手術材料を入 手し, 細胞分散法あるいは培盖条件を可能なか ぎり変化させて初代培盖を試み， $\alpha$ フェトブロ テイン (AFP) やアルフミン (ALB) 麾生産の 推移などの観察を行うとともに, 一系の株化に 成功したので報告する。

\section{材料と方法}

\section{1. 症例}

培養には，Table 1に示した樣に20例の手術 材料を用いた。
2、培管方法

採取された腫瘟組織を，メスにて細片し，さ らに Hanks'液にて洗净後, 0.05\%コラダナーゼ (sigma)，1000u/mlデスパーゼ (合同酒精) そ

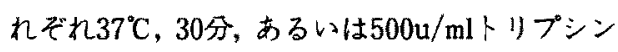

(持田製薬) $4{ }^{\circ} \mathrm{C} 20$ 分から24時間処理しさらに その後 $150 \mu \mathrm{m}$ poreのメッシュに通した。最終濃 度 $10 \%$ 牛胎児血清または $20 \%$ 成牛血清 $\left(56^{\circ} \mathrm{C} 30\right.$ 分非動化以下 $\mathrm{BS}$ と略す) と最終濃度 $0.2 \%$ ラ トアルブミンハイドロリゼイト (GIBCO) を加 えた RPMI-1640（日水）を主な培養液とし（以 下RLと略す), 初代培養の場合は, 全細胞収量 を1〜2枚の35minシャーレ (Falcon)あるいは $35 \mathrm{~mm}$ コラーゲンディシュ（岩城がラス）に播種 し，株細胞の場合は原則的には, 10 万 $/ \mathrm{ml} 4 \mathrm{ml}$ $60 \mathrm{~mm}$ シャーレに播種し， $5 \% \mathrm{CO}_{2}$ インキュベー ター内で静置培荃を行った。

\section{3 . 染色体分析}

対数增殖期にある細胞に0.3\%コルヒチンを添 加した後, 常法 ${ }^{19} に$ に従い作製し，同定可能の分裂 像について分析を行った。

4. 生化学的検索

初代培養あるいは継代培盖後，適当な時点で 培盖液を交換し、さらに 2 日間培盖液を 1200 回 転 5 分遠心した後，その上清について AFP 並U゙

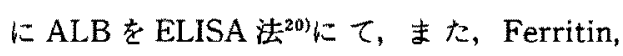
Elastase-1, Tissue Polypetide Antigen (TPA) , $\beta_{2}$-microglobulin (BMG), Carbo- 
Table 1 PRIMARY CULTURE OF HUMAN HEPATOMA

\begin{tabular}{|c|c|c|c|c|c|}
\hline & Age & Sex & $\begin{array}{c}\text { Patient } \\
\text { Diagnosis }\end{array}$ & $\underset{\text { infection }}{\mathrm{HBV}}$ & TAE $^{*}$ \\
\hline $\mathrm{HuH}-15$ & 58 & $\mathrm{M}$ & H.C.C. ${ }^{* *}$ & + & - \\
\hline HuH-16 & 62 & M & H.C.C. & - & + \\
\hline $\mathrm{HuH}-17$ & 73 & $M$ & H.C.C. & - & + \\
\hline $\mathrm{HuH}-18$ & 58 & $\mathrm{M}$ & H.C.C. & - & + \\
\hline $\mathrm{HuH}-19$ & 62 & $\mathrm{~F}$ & H.C.C. & - & + \\
\hline $\mathrm{HuH}-20$ & 44 & $\mathrm{~F}$ & H.C.C. & - & - \\
\hline $\mathrm{HuH}-21$ & 51 & $\mathbf{M}$ & H.C.C. & + & + \\
\hline $\mathrm{HuH}-22$ & 49 & $M$ & H.C.C. & - & - \\
\hline $\mathrm{HuH}-23$ & 63 & $\mathrm{M}$ & H.C.C. & - & - \\
\hline HuH-24 & 57 & $\mathrm{M}$ & H.C.C. & - & + \\
\hline $\mathrm{HuH}-25$ & 57 & M & H.C.C. & + & - \\
\hline HuH -26 & 67 & $\mathrm{M}$ & H.C.C. & - & - \\
\hline $\mathrm{HuH}-27$ & 71 & $\mathrm{M}$ & H.C.C. & - & - \\
\hline HuH -28 & 37 & $\mathrm{~F}$ & C.C.C.*** & - & - \\
\hline HuH -29 & 53 & $\mathrm{M}$ & H.C.C. & + & + \\
\hline $\mathrm{HuH}-30$ & 77 & $\mathrm{M}$ & H.C.C. & + & - \\
\hline HuH-32 & 53 & $\mathrm{M}$ & H.C.C. & + & + \\
\hline $\mathrm{HuH}-33$ & 68 & $\mathrm{~F}$ & H.C.C. & + & - \\
\hline $\mathrm{HuH}-34$ & 68 & $\mathrm{~F}$ & H.C.C. & - & - \\
\hline $\mathrm{HuH}-35$ & 68 & $\mathrm{~F}$ & H.C.C. & - & - \\
\hline
\end{tabular}

Transcatheter arterial embolization

* * Hepatocelluar carcinoma

$* * *$ Cholangiocelluar carcinoma

hydrate Antigen (CA) 19/9, CA-125, Pancreatic Secretory Trypsininhibitor (PSTI) , Immunosuppresive Acidic Protein (IAP) を radioimmunoassay kitにてそれぞれ測定をおこ なった．また，培養上清中のアルカリフォスフ アターゼ (ALP) を King ら $\gamma$-glutamyltranseferase (GGT) をLaishes ${ }^{22)}$ 方法で, さらに, 細胞中の ALP 活性を, $0.93 \mathrm{~mol} /$ $1 \mathrm{AMP}$ 緩衝液（PH10.5）中のP-二トロフォス フェイトから，P-N.ニトロフェニールの遊離を 比色することにより測定した。

\section{5 。異種移植性}

ヌードマウス BALB/Cの背部に, 酥素による 分散細胞ないしは細切した組織片として接種し た. 播種材料は, HuH-15〜24, 26〜30,33の16 例である。株化した HuH-28については，継代 9 代にも接種した。

\section{6. 增殖曲線}

細胞株として樹立された HuH-28については， 7 代(植之込み数 $1.5 \times 10^{4}$ cells/well およU2.5 $10^{4}$ cells/well $)$ 占 $上 U 212$ 代 $\left(4.5 \times 10^{4}\right.$ cells/well $)$ において，また，覀株 HuH-28-1については， 33 代 $\left(3 \times 10^{5} \mathrm{cells} /\right.$ well $)$ によいて, 細胞を 24 穴 マルチウエルディシュ（Faicon）に播種し， 2 週間にわたり，細胞数を計測した。

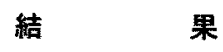

\section{1. 継胞分散}

腫㿋組織からの細胞収量ならびに生存率は, 醳素の種類に関倸なく非常に低く(細胞収量は, 多い例で104cells/g wet tissue, 生存率は約 1 \%),カウント不能な例が多かっったこれは, TAE 非施行例 2 例を除き, 材料の TAE 施行の有無に はとくに関係しなかった. HuH-28, HuH-33の 2 例については，トリプシン处理により比較的 
高い生存率（両者とも約15\%) が得られた，

2. 初代培養における細胞形態

単層培養では, TAE 施行例 $1 / 8$, 非施行例 $4 / 12$ に上皮性細胞を認めた。一方, 移植片培養 法では, TAE 施行例 $1 / 8$, 非施行例 $3 / 12$ に上 皮性細胞の遊出を認めた (Fig. 1). HuH-28と HuH-33を除いて, 上記の上皮性細胞のほとんど は， 1 週間から 3 力月間の間に変性消失した。

HuH-28は, 紡錘形細胞が主であり，一部に多角
形細胞が存在した. HuH-33は多角形細胞とやや 細い角形細胞が 3 力月以上存在し，1988年10月 1 日現在增殖中である。

3. 細胞增殖

ほとんどの細胞系は, 継代に到る前に死滅し た.HuH-28は,ゆっくりとした增殖性を示しな がら継代可能となり細胞株となった ${ }^{23224)}$. その後, 本細胞株より BS 濃度を順次低下させ, $1 \% \mathrm{BS}$ 添加培地で継代可能な亜株 (HuH-28-1)を得た.

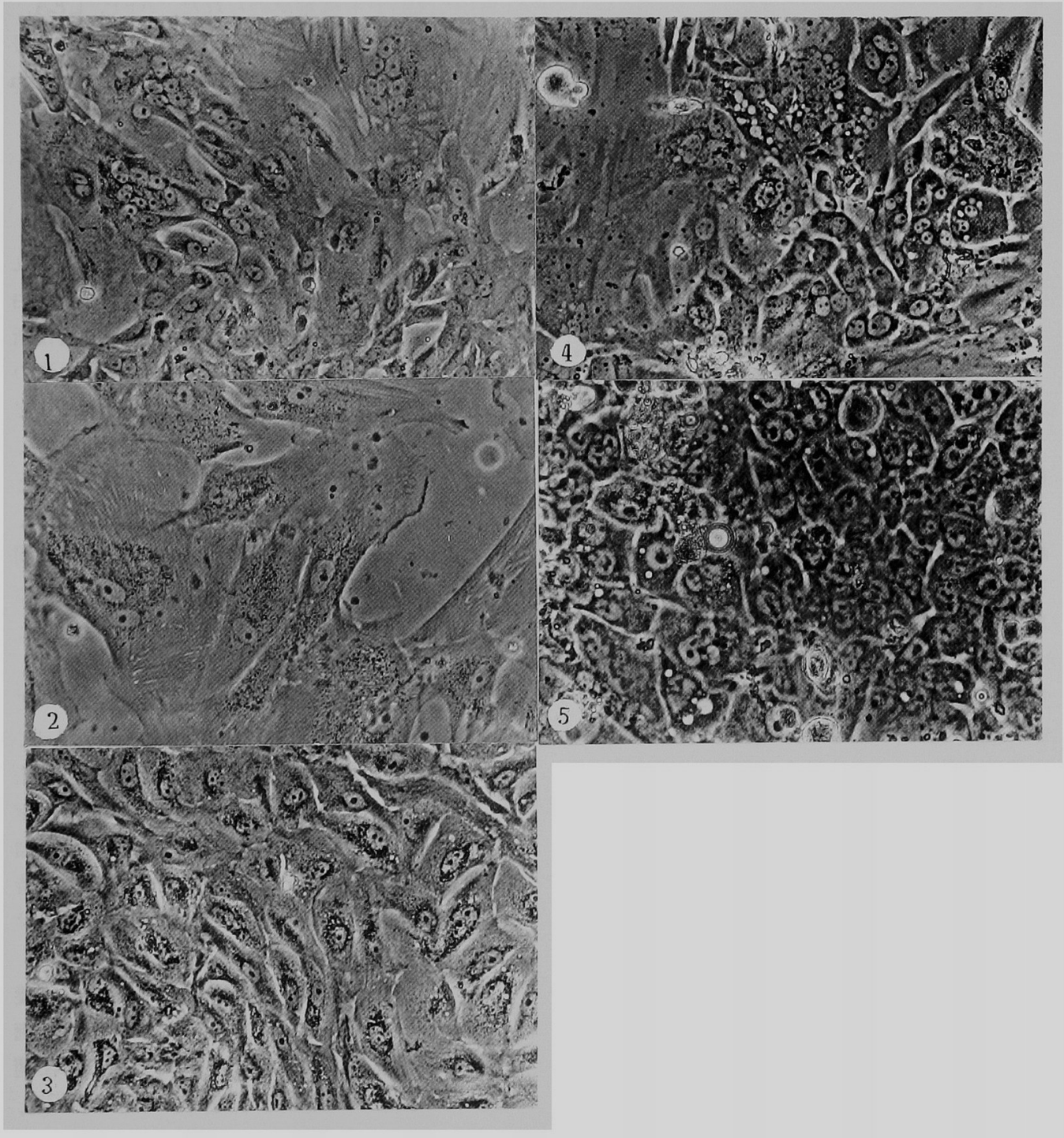

Fig. 1 Epithelial-like cells derived from human primary liver cancer tissues treated with or without TAE. Phase contrast. $\times 100.1$, HuH-21 (TAE +$): 2, \mathrm{HuH}-15$ (TAE -$): 3$, HuH-27 (TAE-) ; 4, HuH-28: (TAE-) : 5, HuH-33 (TAE-). 


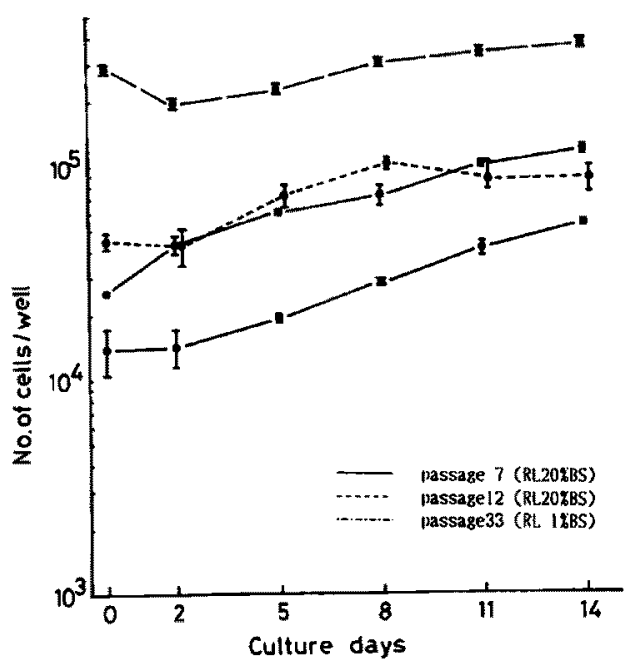

Fig. 2 Growth curves of HuH-28 cultured in RPMI-1640 supplemented with $0.2 \%$ lactalbumin hydrolysate and $20 \%$ BS $(-, \cdots . .$.$) and its subline HuH-28-1$ cultured in RPMI-1640 supplemented with $0.2 \%$ lactalbumin hydrolysate and $1 \%$ BS (-*-). Bars, Mean \pm SD.

Fig. 2 には, HuH-28 (RL+20\% BS) および その亜株 HuH-28-1 (RL+1\% BS) の增殖曲 線を示した. HuH-33は，初代培養後，108日目 に第一回目の継代が可能となった。また，以下 に示寸様に初代培盖後22日目に染色体作製可能 となり，将来樹立細胞系となることが，期待さ れる。

4.AFPならじに ALBの推移

肝癌細胞のマーカーとして AFPおよび ALB の推移を調べた(Table 2). 培地中の AFPは， 1 週間加 1 力月間検出可能であった, 多くの 細胞系は, 細胞の変性とともに AFP 量, ALB 量 とも末検出となった。

HuH-33は101日現在, 微量ながら AFP および ALB ともなお検出可能であり観察される上皮性 細胞は，肝癌細胞であることが考えられた。

5. 染色体分析

HuH-28およU゙HuH-33か染色体作製可能とな った，HuH-28では，継代 3 代ならびに14代にお いて，染色体はすへてて人型で，染色体数は，4090の範围に分布し、モードは、いずれも59であ
った.HuH-33では, 初代培養後22日目に染色体 作製を行い，異数体性が観察された（Fig. 3). 6. 異敇移植性

移植後 2 力月から 6 力月の時点で腫瘤形成を 認めていない。

7. 生化学的検索

HuH-28およびその亜株 HuH-28- 1 の培養上 清について生化学的検索を行った結果, Ferritin, Elastase- 1，BMG，TPAを検出した。 また， ALP, GGT も微量認妨られた. AFP, CEA, CA-19/9などは検出されなかった (Table 3). また, ALPの細胞内活性は, 165mU/mg protein であった。

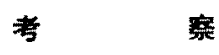

ヒト肝癌組織の培盖，株化に関する報告は， その多くが1985年までになされているが，それ 以後は，やや少なくなる洒向にある，その理由 として，神代らが述べている ${ }^{1825)}$ 樣に，診断技術 の向上，外科的手術，化学ならじに免疫療法の 発達等が上げられるが，特に化学療法剂やリピ オドールと併用される TAEの普及 ${ }^{261-33) に よ り ， ~}$ 生きた肝癌細胞を得がたくなったことによると 考えられる。著者らが知りうる限りにおいては， TAE 施行に言及した初代培盖あるいは株化に関 する報告は未だ無い.今回行ったTAE 施行また は非施行肝癌組織の初代培盖の試行結果をもと に以下に問題点を上げ，考察を加える.

1. 初代培養法 (細胞分散法, 培養法)について

入手材料の大きさ，部位その他に制限があり， 系統的な実験は不可能であったが，細盷分散法 に関しては、コラダナーゼあるいはデスパーゼ 法に比し，トリプシン法により生存率がやや增 加する例を認めた。トリブシンでは，低温長時 間処理が可能であり，それだけ細胞賃害が避け られるのかししれない。

培養法に関しては，各材料について単層培盖 法と移植片培養法の二法を適用した，上皮性細 胞の出現，AFP あるいはALBの消長などに関 し，而培養法の間に大きな差異を認めなかった。 今後，コラーダンゲル内培羕法など、マトリッ クスを考虑した培養法も検討されなければなら ないと考えられた。 
Table 2 Production of $\alpha$-fetoprotein and albumin in human hepatoma cells after primary culture

\begin{tabular}{|c|c|c|c|c|c|c|c|}
\hline & \multirow{2}{*}{$\begin{array}{l}\text { Pre-operation } \\
\text { AFP }(\mathrm{ng} / \mathrm{ml})\end{array}$} & & \multicolumn{5}{|c|}{ Time after primary culture } \\
\hline & & & 0 & $1 w$. & $1 \mathrm{~m}$ & $2 \mathrm{~m}$. & $3 \mathrm{~m} .(\mathrm{ng} / \mathrm{ml})$ \\
\hline \multirow[t]{2}{*}{$\mathrm{HuH}-15$} & 415 & AFP & & & $\mathrm{ND}^{*}$ & & \\
\hline & & ALB & & & 35 & 4 & 1 \\
\hline \multirow[t]{2}{*}{$\mathrm{HuH}-16$} & 21.3 & AFP & & ND & & & \\
\hline & & ALB & & $>100$ & & & \\
\hline \multirow[t]{2}{*}{$\mathrm{HuH}-17$} & 6.8 & AFP & & & ND & & \\
\hline & & ALB & & & 4 & & \\
\hline \multirow[t]{2}{*}{ HuH-18 } & 14 & AFP & & ND & ND & & \\
\hline & & ALB & & 14 & 3 & 2 & \\
\hline \multirow[t]{2}{*}{ HuH-19 } & 742 & AFP & & & & 2 & \\
\hline & & ALB & & & & 2 & \\
\hline \multirow[t]{2}{*}{$\mathrm{HuH}-20$} & 508 & AFP & & & & 4 & \\
\hline & & ALB & & & & 2 & \\
\hline \multirow[t]{2}{*}{$\mathrm{HuH}-21$} & 61.6 & AFP & & ND & 2 & ND & \\
\hline & & ALB & & 77 & 3 & 1 & \\
\hline \multirow[t]{2}{*}{$\mathrm{HuH}-22$} & 34.5 & AFP & & & 2 & & \\
\hline & & ALB & & & 5 & & \\
\hline \multirow[t]{2}{*}{$\mathrm{HuH}-25$} & 20.3 & AFP & & ND & & & \\
\hline & & ALB & & $>100$ & & & \\
\hline \multirow[t]{2}{*}{$\mathrm{HuH}-26$} & 5600 & AFP & & 9 & & & \\
\hline & & ALB & & $>100$ & & & \\
\hline \multirow[t]{2}{*}{$\mathrm{HuH}-27$} & 111.9 & AFP & & & 22 & & \\
\hline & & ALB & & & 2 & & \\
\hline \multirow[t]{2}{*}{$\mathrm{HuH}-33$} & 4300 & AFP & & ND & ND & & 5 \\
\hline & & ALB & & ND & $\mathrm{ND}$ & & 4 \\
\hline
\end{tabular}

* Not detected

2. TAE 施行の影響について

単層培盖法において（移植片培養法において もほほ同様の傾向であったが), 上皮性細胞の出 現の割合が, TAE 施行例 $1 / 8$ に対し，非施行 例 $4 / 12$ と非施行例が上回った. さらに，継代の 可能性に関しても, 可能となった二系(HuH-28, HuH-33)はいずれも TAE 非施行例である. TAE 非施行例に㧍いても当然のことながら制癌剂処 置がなされており，その影響が残存していると 考之られるが，上記の結果より，TAE施行が肝 癌細胞の傷書をより強く残していることが示唆 され，今後，肝癌の手術材料としては可能な限 ク TAE 非施行例の使用か望ましいと思われる。

3. HuH-28の株化についてて ${ }^{23)-24)}$

今日までに報告のあった胆管細胞癌株は著者 らの知りうる限りでは, 数例 ${ }^{15)-17)} し か$ 無く, ま
たいずれも上皮様形態を保持している.HuH-28 は, in vivo 反映する形態，すなわち紡錘型を 主とし多角型細胞の漉在も認められ，新しい夕 イプの胆管細胞癌株と思われる。また，他の胆 管細胞癌株と比較して，低い增殖率ながら，早 期より安定な增殖性を示す一方で，染色体は， 3 代においてすでに簧常を示し，モード59は14 代においても維持されていた。こことは, HuH28が長期培着においても in vivoにおける生物学 的性状を比較的よく保持していることを示して いるのかもしれない。

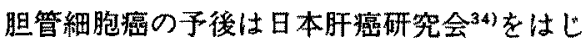
めとして、種々の報告35136)でいずれも非常に子後 不良とされている。しかしながら，本 HuH-28の 宿主たる患者はリリン八゙節転移や再発を認めな がら 4 年以上も存命中であることより予後は比 


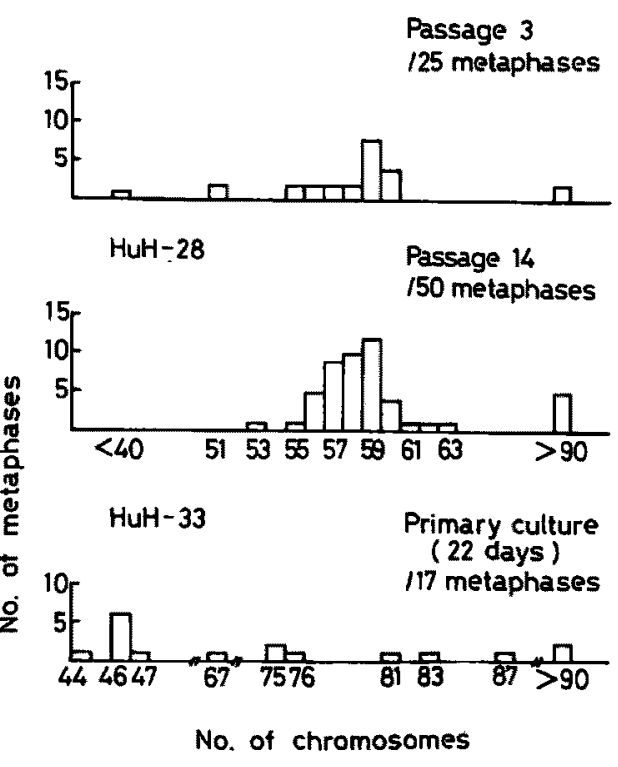

Fig. 3 The distribution of chromosome numbers in HuH-28 at passage 14 and in $\mathrm{HuH}-33$ at primary culture.
較的良好と考之られ，低い堌殖性ならびに異種 移植性の欠如とも併せて in vivo $と$ in vitroの 関連性という点で興味樑い。

HuH-28は，胆道系酵素群であるALPならび に GGT 陽性であった。また，培養上清中には， AFP CEA CA19-9は認めず, BMG Ferritin TPA Elastase-1 認め, 機能的にも特徴的な 胆管細胞癌株であると思われる。

\section{結論}

我々は，最近の種々の治療を施された手術材 料（19例の肝細胞癌と 1 例の胆管細胞癌）を用 いた場合のヒト肝癌細胞株を得る可能性を探る ため，初代培盖を行った。

1、䣼素処理による細胞分散時の生存率は, TAE 施行の有無に関わらず1\%以下であった。 2 . 単層培盖法では, TAE 施行 8 例中 1 例, 非 施行12例中 4 例に上皮性細胞を認的た。一方 移植片培盖法では TAE 施行 8 例中 1 例，非 施行12例中 3 例に上皮性細胞の遊出を認めた。 これら上皮性細胞は 1 週間 1 力月の間 $\mathrm{AFP}$

Table 3 Tumor markers in spent media by HuH.28 and its subline HuH-28- 1

HuH-28 (passage $3, \mathrm{RL}+20 \% \mathrm{BS}$ )

\begin{tabular}{|c|c|c|}
\hline CEA & $<0.5 \mathrm{ng} / \mathrm{ml}$ & \\
\hline CA19-9 & $<5.0 \mathrm{u} / \mathrm{ml}$ & \\
\hline $\mathrm{BMG}$ & $700 \quad \mu g / 1$ & $\mu \mathrm{g} / 10^{4} \mathrm{cells}$ \\
\hline Ferritin & $9 \mathrm{ng} / \mathrm{ml}$ & $0.19 \mathrm{ng} / 10^{4} \mathrm{cells}$ \\
\hline TPA & $99 \mathrm{mu} / \mathrm{ml}$ & $2.06 \mathrm{mu} / 10^{\circ} \mathrm{cells}$ \\
\hline Elastase-1 & $6000 \quad \mathrm{ng} / \mathrm{ml}$ & $125 \mathrm{ng} / 10^{4}$ cells \\
\hline PSTI & $<2.0 \mathrm{ng} / \mathrm{ml}$ & \\
\hline IAP & $<50 \quad \mu \mathrm{g} / \mathrm{ml}$ & \\
\hline CA12-5 & $<5.0 \mathrm{u} / \mathrm{ml}$ & \\
\hline$y-\mathrm{GTP}$ & $4.01 \mathrm{mu} / \mathrm{ml}$ & $0.081 \mathrm{lu} 10^{4} \mathrm{cells}$ \\
\hline ALP * & $12.3 \mathrm{lu} / \mathrm{ml}$ & \\
\hline AFP * & $<3.0 \mathrm{ng} / \mathrm{ml}$ & \\
\hline
\end{tabular}

* Examined at passage 1 (ALP) and 6 (AFP), respectively.

HuH-28- 1 (passage 28, RL $+1 \%$ BS)

\begin{tabular}{|c|c|c|}
\hline CA19-9 & $<5.0 \mathrm{u} / \mathrm{ml}$ & \\
\hline $\mathrm{BMG}$ & $322 \mu \mathrm{g} / 1$ & $1.40 \mu \mathrm{g} / 10^{6} \mathrm{cells}$ \\
\hline Ferritin & $8 \mathrm{ng} / \mathrm{ml}$ & $34.8 \mathrm{ng} / 10^{6} \mathrm{cells}$ \\
\hline TPA & $36 \mathrm{mu} / \mathrm{ml}$ & $156.5 \mathrm{mu} / 10^{6} \mathrm{cells}$ \\
\hline Elastase-1 & $1110 \mathrm{ng} / \mathrm{l}$ & $4.8 \mathrm{ng} / 10^{6}$ cells \\
\hline
\end{tabular}


産生能とともに培盖内で維持された。

3.上皮性細胞を認めた 7 例中，継代可能とな つたものは, 単層培養法由来の $\mathrm{TAE}$ 非施行例 2 例のみであった.そのうち 1 例は CCCであ ク，その後 CCC の諸性質を有する細胞株の樹 立に到った。

4、ヌードマウスへの移植性は調べられたすぺ
ての例で㓌性であった。 以上の結果は, TAE 施行例のみならず非施行例 においても継代可能な上皮性細胞を得るには， 相当な困難を伴い，培盖条件その他に関し特別 な工夫がなされなければならないことを示して いる.

\section{文}

1) Doi I, Namba M and Sato J : Establishment and some biologycal characteristics of Human Hepatoma cell lines. Gann (1975) 66, 385-392.

2) Alexander JJ, Bey EM, Geddes EW and Lecatsas G : Establishment of a continuously growing cell line from primary carcinoma of the liver. S Afr J Med J (1976) 50, 2124-2128.

3) Doi $I$ : Establishment of a cell line and its clonal sublines from a patient with hepatoblastoma. Gann (1976) 67, $1-10$.

4) Chen JM, Chu TH, Yen HJ and Shen TW: The establishment and some characteristics of a human liver carcinoma cell line (BEL-7402) in vitro. Acta Biol Exp Sin (1978) 11, 37-50.

5) Aden DH, Fogel A, Plotkin S, Damjianov I and Knowles BB : Controlled synthesis of HBs-Ag in a differentiated human liver carcinoma-derived cell line. Nature (1979) 282, 615-616.

6) Chen JM, Chu TH, Yen HJ, Shen TW and Lu YH : Establishment of three human liver carcinoma cell lines and some of their biologycal caracteristics in vitro. Sci Sin (1980) 23, 236-251.

7) $\mathrm{HuH} \mathrm{N}$ and Utakoji $\mathrm{T}$ : Production of HBs-antigen by two new human hepatoma cell lines and its enhancement by dexamethasone. Gann (1981) 72, 178-179.

8) Nakabayashi H, Taketa $\mathrm{K}$, Yamane $\mathrm{T}$ and Sato $\mathrm{J}$ : Growth of Human Hepatoma cell lines with Differentiated Function in chemically Defined medium. Cancer Res (1982) 42, 3858-3863.

9) Watanabe T, Morizane T, Tsuchimoto K, Inagaki Y, Munakata Y, Nakamura T, Kumagai N and Tsuchiya $\mathrm{M}$ : Establishment of a cell line (HCC-M) from a human hepatocelluar carcinoma. Int J Cancer (1983) 32, 141-146.

10) He L, Isselbacher KJ, Wands JR, Goodman HM, Shin C and Quarori A : Establishment and Caracterizasion of a new Human Hepatocellular Carcinoma cell line. IN VITRO (1984) 20, 493504.

11）村上龍夫：七卜肝癌細胞株（KIM-1）の樹立と性状. 肝瀻（1984）25，1-8.

12) Yano $\mathrm{H}, \mathrm{Kojiro} \mathrm{M}$ and Nakashima $\mathrm{T}$ : A new human hepatocellular carcinoma cell line (KYN-1) with a Transformation to adenocarcinoma. IN VITRO (1986) 22, 637-646,

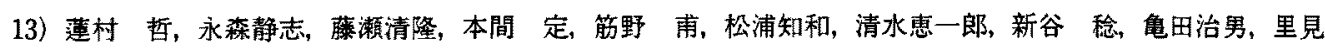
信子，原中腾征：ヒ卜肝癌細胞怢に对する tumor necrosis factor の影響。医のあゆみ（1987）143，655656.

14) Yano $H$, Maruiwa $M$, Murakami $T$, Fukuda $K$, Ito $Y$, Sugihara $S$ and Kojiro $M$ : A new human pleomorphic hepatocellular carcinoma cell line, KYN-2. Acta Pathol Jpn (1988) 38, 953-966.

15) Yamaguchi N, Morioka H, Ohkura $H$, Hirohashi $S$ and Kawai $K$ : Establishment and Characterization of the Human Cholangiocarcinoma cell line HChol-Y 1 in a serum-free, Chemically defined medium. J Natl Cancer Inst (1985) 75, 29-32. 
16）宮際 幹，市田隆文，佐々木博，常盤孝義，佐藤二郎：CA19/9 高産生性七卜胆管細胞癌由来細胞の樹立と その性状。上卜細胞研究会抄録集（1987）5，46-49.

17）松浦知和，永森静志：ヒト那・胆・膵細胞の樹立株；JHC一1。第四回人細胞研究会シンポジウム抄碌集 (1987) 70 .

18）神代正道，中島敏郎：病理：肝癌，末好恵一，服部 信編，メジカルビニー社，東京（1986）pp114-122.

19) Rothfels $\mathrm{KH}$ and Siminovitch $\mathrm{L}$ : An air drying technique for flattening chromosomes in mammalian cells grown in vitro. Stain Technol (1958) 33, 73-77.

20) Uotila $M$, Ruoslahti $E$ and Engvall $E$ : Two site sandwitch enzyme immunoassay with monoclonal ansibodies to human alpha-fetoprotein. J Immunol Methods (1981) 42, 11-13.

21) King EJ, Haslewood GAD, Delory GE and Beall $D$ : Micro-chemical methods of blood analysis. Lancet (1942) 1, 207-209.

22) Laishes BA, Ogawa $K$, Roberts E and Farber E : Gamma-Glutamyl Transpeptidase : A Positive Marker for Cultured Rat Liver Cells Derived from Putative Premalignant and Malignant Lesions. J Natl Cancer Inst (1978) 60, 1009-1016.

23) Kusaka $Y$, Tokiwa $T$ and Sato $J$ : Establishment and characterization of a cell line from a human cholangiocelluar carcinoma. Res Exp Med (1988) 188, 367-375.

24）日下泰德, 村间 篤, 常盤孝義, 佐藤二郎：七卜胆管細胞癌由来細胞株 HuH-28の樹立と性状. Human Cell (1988) $1,92-93$.

25）神代正道：肝細胞癌培養株の機能分化維持. 医の孛内及（1987）141，193.

26）打田日出夫：Interventional Angiography：とくに腹部領域における Transcatheter arterial emboliza. tionに上る治潦。日独医報（1979）24，475一-479.

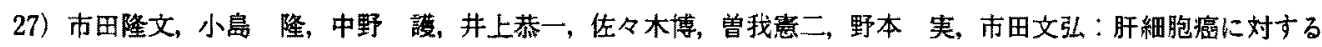
Transcatheter Arterial Embolization 療法の臨床病理学的梌討. 肝臟（1981）22，1264-1275.

28）中村仁信, 田中 健, 崔秀美, 川本誠一, 森本耕治, 堀 信一, 吉岡寛康：肝悪性腫演に对主る Transcatheter Embolization；切除例加らみ効果判定. 脈管学 (1982) 22，335-339。

29）佐々木洋, 今岡真義, 松井征雄, 石川 治, 谷口健三, 岩永 凪, 寺沢敏夫,大川元臣, 石黑信吾, 堀 信 一：肝稩胞癌における術前 Transcatheter arterial embolization therapyの意義について；組織学的検討 を中心认，日癌治㙩会誌（1982）17，1917-1924.

30）平井䁈治, 熊谷雅信, 大久保和典, 川副良治, 酒井輝文, 長崎嘉和, 阿部雅秀, 久保保彦, 谷川久一：肝細 胞癌における肝門部門脈側副路の㬈床的意義。臨放線（1984）29，451-455.

31）池田健次，小宅映士，能田博光，竹内和男，中島正男，吉場 朗，煎本正博：肝癌に对する transcatheter arterial embolization therapy の評価. 日消外会誌 (1984) 81，249-253.

32）木村通雄，小林敏生，大藤正雄：成績からみた TAE 療法の検討。臨外（1984）39，987-993.

33）長島 通, 滝 崇正, 向井 稔, 策池俊之, 有我隆光, 高 在完, 奥山和明, 山本義一, 小高通夫, 佐藤 博： 肝悪性種瘍に対する lipiodol-adriamycin 動注療法の検討。日消外会誌（1985）18，1664-1670。

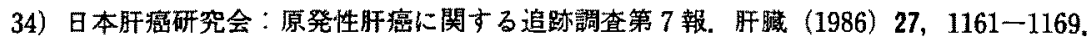

35）水戸廸郎，近藤罂史，沢 雅之：胆管細胞癌。肝癌, 末舛恵一, 服部 信編メジカルビュー社, 東京 (1986) pp173-181.

36) Foster JH : Survival after liver resection for cancer. Cancer (1970) 26, 493-502. 
Primary culture of human primary liver cancer tissues treated with or without transcatheter arterial embolization and establishment of a cell line Yasunori KUSAKA", Takayoshi ToKIWA", Hiroshi TsugE ${ }^{21}$ Keisuke Hamasaki ${ }^{2)}$, Hisashi Mimura", Kunzo ORITA ${ }^{2)}$ and Jiro SAT0"

1) Division of Pathology, Cancer Institute, Okayama University Medical School, Okayama 700, Japan

2) First Department of Surgery, Okayama University Medical School, Okayama 700, Japan

(Director : Prof. J. Sato)

Primary culture of human primary liver cancer tissues treated with or without trancatheter arterial embolization (TAE) was perfomed with the following results.

1. The yield and viability were very low in cells from primary liver cancer tissues dissociated with enzymes.

2. Epithelial-like cells were found from TAE-treated cancer tissues at a ratio of $1 / 8$ in both monolayer and explant culture and from TAE-nontreated tissues at a ratio of $4 / 12$ in monolayer culture and $3 / 12$ in explant culture. The AFP-producing capahity of these epithelial-like cells has been maintained from one week to one month in culture.

3. Cells derived from two TAE-nontreated cancer tissues were subculturable. One was established as a cholangiocellular carcinoma cell line.

4. No heterotransplantability of primary cultured cancer cells into nude mice was found. 